\title{
FORMULASI DAN UJI EFEKTIVITAS ANTIBAKTERI EDIBLE FILM EKSTRAK BIJI PINANG (Areca catechu Linn)
}

\author{
Wida Ningsih
}

${ }^{1,2}$ Universitas Muhammadiyah Sumatera Barat

Jalan Pasie Nan Tigo Koto Tangah Padang

Email: nwida777@gmail.com

\section{INTISARI}

Tanin yang terkandung dalam ekstrak biji pinang dapat menghambat pertumbuhan bakteri Streptococcus mutans. Untuk mempermudah penggunaan ekstrak biji pinang sebagai antibakteri diformulasi menjadi bentuk edible film dengan konsentrasi 2,5\%,3\% dan 3,5\%. Pembuatan edible film menggunakan metoda solvent casting dan pengujian aktivitas antibakteri menggunakan metoda difusi agar darah. Edible film ekstrak biji pinang yang dibuat dilakukan evaluasi meliputi organoleptis, ketebalan, kerapuhan, kandungan air, $\mathrm{pH}$, dan uji swelling. Hasil evaluasi edible fim ekstrak biji pinang menunjukan karakteristik yang hampir sama dengan edible fim yang sudah beredar dipasaran yang digunakan sebagai pembanding. Adanya aktifitas antibakteri dari edible film ekstrak biji pinang ditandai terbentuknya zona bening. Hasil pengujian aktifitas antibakteri edible film ektrak biji pinang $2,5 \%, 3 \%$ dan 3,5\% menunjukan diameter rata-rata zona bening rata $14,96 \mathrm{~mm}, 15,49 \mathrm{~mm}$ dan $17,05 \mathrm{~mm}$ yang termasuk kategori kuat.

Kata kunci: Biji Pinang, antibakteri, edible film, tannin, streptococcus

\section{ABSTRACT}

The tannins contained in areca nut extract can inhibit the growth of Streptococcus mutans bacteria. To facilitate the use of betel seed extract as an antibacterial, it was formulated into an edible film with a concentration of $2.5 \%, 3 \%$ and $3.5 \%$. Making edible films using solvent casting method and testing antibacterial activity using blood agar diffusion method. The edible film of areca nut extract made an evaluation included organoleptic, thickness, brittleness, water content, $\mathrm{pH}$, and swelling test. The evaluation results of betel nut edible fim extract showed almost the same characteristics as the edible fim that had been circulating in the market which was used as a comparison. The presence of antibacterial activity from edible pinang seed extract is marked by the formation of clear zones. The test results of antibacterial edible activity of areca nut extract films $2.5 \%, 3 \%$ and $3.5 \%$ showed the average diameter of clear zone was $14.96 \mathrm{~mm}, 15.49 \mathrm{~mm}$ and $17.05 \mathrm{~mm}$ which were included in the strong category.

Keywords: Areca catechu Linn, antibacterial, edible film, tannin, streptococcus

Corresponding author:

Wida Ningsih

Universitas Muhammadiyah Sumatera Barat

Jalan Pasie Nan Tigo Koto Tangah Padang

Email: nwida777@gmail.com

\section{PENDAHULUAN}

Halitosis merupakan istilah umum yang digunakan untuk menggambarkan nafas tidak sedap yang berasal dari rongga mulut maupun diluar rongga mulut. Penyebab dari rongga mulut biasanya karena perawatan kebersihan mulut yang buruk, karies gigi, infeksi rongga mulut, mulut kering, mengonsumsi rokok, sisa makanan dalam mulut (Brotosoetarno, 1997; Cortelli et al., 2008). 
Faktor-faktor dari luar rongga mulut yang menjadi penyebab halitosis, antara lain infeksi saluran pernafasan, infeksi gastrointestinal, karsinoma, dan diabetes (Van de Broek et al., 2008). Kondisi yang dapat memicu bau mulut ialah meningkatnya bakteri dalam mulut, kurangnya flow saliva, $\mathrm{pH}$ rongga mulut yang lebih bersifat alkali dan adanya sisa makanan yang tertinggal yang diproses oleh flora normal mulut (Widagdo dan Suntya, 2007). Selain itu, koloni bakteri yang ditemukan pada awal pembentukan plak adalah bakteri Streptococcus mutans yang banyak diyakini para ahli sebagai penyebab utama terjadinya karies pada gigi (Michalek and Mc Ghee, 1982). Pertumbuhan Streptococcus mutans harus dihambat agar tidak menjadi patogen dan menyebabkan karies dengan pemberian bahan antibakteri. Salah satu cara pencegahan karies adalah mengusahakan agar pembentukan plak pada permukaan gigi dapat dibatasi baik dengan cara mencegah pembentukannya atau dengan pembersihan plak secara teratur. Pengendalian plak dapat dilakukan dengan cara pembersihan plak secara mekanis dan kimia yang mengandung bahan anti kuman yang dapat menekan pertumbuhan Streptococcus mutans. Streptococcus mutans merupakan bakteri yang dapat menyebabkan karies gigi karena Streptococcus mutans mempunyai kemampuan membuat polisakarida ekstraseluler yang dapat menyebabkan matrik plak sehingga membantu bakteri untuk melekat pada gigi (Pratiwi, 2005).

Biji pinang tumbuhan yang mengandung tannin terkondensasi, tannin terhidrolisis, flavonoid, senyawa fenolik, asam galat dan 0,3-0,6 \% alkaloid seperti arekolin $\left(\mathrm{C}_{8} \mathrm{H}_{13} \mathrm{NO}_{2}\right)$, arekolidin, arekain, guvakolin, guvasine, dan isoguvasine (Wang and Lee, 1996). Senyawa antibakteri biasanya terdapat pada golongan senyawa saponin, fenolat, flavonoid, terpenoid, steroid dan alkaloid (Panjaitan, 2008).

Edible film merupakan lapisan tipis yang terbuat dari bahan-bahan yang dapat di kon sumsi, digunakan untuk melapasi makanan, proses pengawetan, melindungi makanan dari mikroorganisme, memperbaiki penampilan produk, pembawa senyawa antibakteri, dan mencegah hilangnya kualitas makanan (Krochta, 1992).

\section{METODE PENELITIAN}

Metode penelitian meliputi : alat alat gelas, kertas perkamen, timbangan digital, lemari pendingin, botol maserasi, kertas saring, tabung reaksi, rak tabung reaksi, pipet tetes, rotary evaporator, hot plate, magnetic stirrer, batang pengaduk, oven, furnace, desikator, pinset, spatel, alat cetak edible film hasil modifikasi, alat uji ketebalan film (mikrometer skrup), $\mathrm{pH}$ meter Inolab, dan Roche friabilator, cawan petri, erlenmeyer, penjepit, inkubator, LAF (Laminar Air Flow), autoklaf, mikroskop, Spektrofotometer UV-Vis, lampu spritus, jarum ose, kapas steril, koran bekas, kain kasa steril.

Bahan-bahan yang digunakan adalah biji pinang, etanol $96 \%$, etanol $70 \%$, pati jagung, HPMC, sorbitol 70\%, Na-sakarin, minyak permen, menthol, nipagin, nipasol, kloroform, $\mathrm{FeCl}_{3}$, $\mathrm{HCl}_{(\mathrm{p})}$, serbuk $\mathrm{Mg}$, norit, $\mathrm{H}_{2} \mathrm{SO}_{4(\mathrm{p})}$ dan aquadest, biakan bakteri Streptococcus mutans, media blood agar base, Dimethyl Sulfoxide (DMSO), larutan $\mathrm{NaCl}$ fisiologis, Pembanding "Go Fresh" (PT. Aquasolve Sanaria).

\section{JALANNYA PENELITIAN}

\section{Ekstraksi}

Buah pinang dibelah dua, diambil bagian dalam yang lunak, dibuang kulitnya, dicuci, dipotong dengan ketebalan 2-5 mm dan dikeringkan \pm 1 minggu kemudian diserbukkan dan ditimbang sebanyak $1000 \mathrm{~g}$. Satu bagian serbuk biji pinang ditambahkan 10 bagian pelarut. Pelarut yang digunakan adalah etanol $70 \%$. Ekstrak dibuat dengan cara maserasi, dimana sampel dimasukkan dalam botol berwarna gelap yang terlindung dari cahaya matahari. Dimasukkan $1000 \mathrm{~g}$ serbuk kering simplisia ke dalam botol bewarna gelap, ditambahkan $10 \mathrm{~L}$ etanol $70 \%$. Sampel direndam selama 6 jam pertama sambil sekali-sekali diaduk, kemudian didiamkan selama 18 jam. Maserat dipisahkan dengan cara filtrasi. Penyarian diulangi sekurang-kurangnya dua kali dengan jenis pelarut yang sama dan jumlah pelarut yang sesuai (sampai sampel terendam). Dikumpulkan semua maserat, kemudian dipekatkan dengan rotary evaporator (Departemen Kesehatan Republik Indonesia, 2011). 


\section{Pembuatan edible film Ekstrak Biji Pinang (Areca catechu Linn)}

Pati jagung didispersikan dalam beberapa bagian aquadest kemudian dipanaskan pada suhu \pm $60^{\circ} \mathrm{C}$, diaduk hingga terbentuk gel jernih. HPMC dikembangkan dalam aquadest ditambah sorbitol, diaduk pada suhu yang dijaga $\pm 60^{\circ} \mathrm{C}$. Kedua gel dicampurkan pada suhu $\pm 60^{\circ} \mathrm{C}$, ditambah bahanbahan yang lain (larutan natrium sakarin, ekstrak biji pinang, nipagin, nipasol, mentol, minyak permen, dan sisa air) pada suhu kamar, diaduk homogen lalu dituangkan dan diratakan pada cetakan $(27,5 \times 18 \mathrm{~cm})$. Pengeringan dilakukan di dalam oven pada suhu $40-45^{\circ} \mathrm{C}$ selama $18 \mathrm{jam}$, lalu dilepaskan dari cetakan lalu dipotong dengan ukuran 2,2 x 3,2 cm (Arifin et al.,2010).

\section{Pengujian aktivitas antibakteri edible film ekstrak biji pinang}

a. Pengujian aktivitas antibakteri Streptococcus mutans terhadap ekstrak biji pinang

Sebanyak $0,5 \mathrm{~mL}$ suspensi mikroba dimasukkan ke dalam cawan petri, lalu ditambahkan $10 \mathrm{~mL}$ blood agar dan dihomogenkan. Setelah media padat, selanjutnya kertas cakram steril ditetesi dengan $10 \mu \mathrm{L}$ sediaan uji kemudian diinkubasi pada suhu $37^{\circ} \mathrm{C}$, selama \pm 24 jam. Diamati pertumbuhan bakteri dan diukur diameter daya hambat ditandai dengan adanya area bening yang menandakan daerah yang tidak ditumbuhi oleh bakteri. Pengujian dilakukan terhadap ekstrak biji pinang 2,5\%,3\%,3,5\%, sebagai kontrol negatif DMSO.

b. Pengujian aktivitas antibakteri edible film ekstrak biji pinang

Sebanyak $0,5 \mathrm{~mL}$ suspensi mikroba dimasukkan ke dalam cawan petri, lalu ditambahkan $10 \mathrm{~mL}$ media blood agar dan dihomogenkan. Setelah media padat, selanjutnya lembaran film berdiameter $5 \mathrm{~mm}$ diletakkan di atas media agar kemudian diinkubasi pada suhu $37^{\circ} \mathrm{C}$, selama \pm 24 jam. Diamati pertumbuhan bakteri dan diukur diameter daya hambat ditandai dengan adanya area bening yang menandakan daerah yang tidak ditumbuhi oleh bakteri. Pengujian dilakukan terhadap sediaan F1, F2, F3 dan sebagai kontrol negatif basis edible film, pembanding sediaan yang sama $\left(\mathrm{GF}^{\circledR}\right)($ Amaliya dan Putri, 2014).

\section{ANALISIS DATA}

Data hasil pengujian aktivitas antibakteri ekstrak biji pinang dalam sediaan edible film diolah secara statistik dengan analisis variasi (ANOVA) satu arah. Hasil akan berarti bila perbandingan daya hambat pada setiap formula memberikan perbedaan yang nyata dan bermakna secara statistik.

\section{HASIL PENELITIAN DAN PEMBAHASAN}

\section{Karakterisasi ektrak buah pinang}

Karakterisasi parameter spesifik ekstrak biji pinang yang dilakukan meliputi organoleptis sesuai dengan yang tercantum pada buku farmakope herbal, sedangkan kelarutan ekstrak biji pinang dalam air termasuk klasifikasi larut dan dalam etanol termasuk klasifikasi mudah larut serta pH dari ektrak biji pinang 5,14. Parameter non spesifik ektrak biji pinang seperti susut pengeringan dan kadar abu sebesar 3,54 \% dan 1,13\%. Hasil yang didapatkan tidak melebihi dari yang ditetapkan pada farmakope herbal. Pemeriksaan fitokimia ekstrak biji pinang menunjukan biji pinang mengandung senyawa fenolik, flavonoid, saponin, steroid, alkaloid dan tanin (Febriani et $a l, 2014)$.

\section{Evaluasi Edible FilmOrganoleptis}

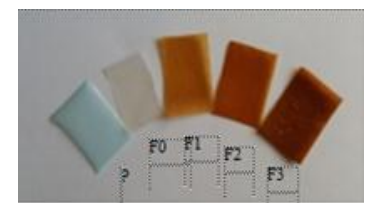

Gambar 1. Hasil Pemeriksaan Organoleptis masing-masing formula

Pemeriksaan organoleptis edible film dilakukan selama 6 minggu menunjukan bentuknya berupa lapisan tipis untuk semua formula. Sedangkan untuk warna edible film terlihat berbeda yang disebabkan karena perbedaan konsentrasi ekstrak pada setiap formula dimana pada formula yang mengandung ekstrak berkonsentrasi besar warnanya akan semakin berwarna coklat transparan, begitu juga rasa edible film terdapat perbedaan semakin besar konsentrasi ekstrak maka rasa edible 
film terasa manis sedikit kelat. Edible film yang disimpan selama 6 minggu terlihat stabil karena tidak menunjukan perubahan bentuk, warna dan rasa selama penyimpanan.

\section{Uji Kerapuhan}

Uji kerapuhan berguna untuk melihat ketahanan edible film selama proses pembuatan dan distribusi. Pengujian ini menggunakan alat Roche Friabilator. Hasil pengujian kerapuhan edible film sebagai berikut $\mathrm{F} 0=0,158 \%, \mathrm{~F} 1=0,181 \%, \mathrm{~F} 2=0,201 \%, \mathrm{~F} 3=0,280 \%, \mathrm{P}=0,145 \%$. F3 menunjukan lebih rapuh dibandingan dengan semua formula dan pembanding. Pada saat pengujian tidak terlihat edible film yang rusak tetapi bagian tepi edible film terlihat sedikit patah terutama untuk F3.

\section{Susut Pengeringan}

Susut pengeringan dilakukan untuk melihat kandungan air dan jumlah senyawa yang hilang pada suhu pemanasan $105{ }^{\circ} \mathrm{C}$. Hasil pemeriksaan susut pengeringan edible film, didapatkan nilai susut pengeringan F0, F1, F2, F3 dan P secara berurutan adalah 13,81\%, 13,48\%, 13,72\%, 13,73\% dan $11,70 \%$.

\section{Pengukuran pH}

Pengukuran $\mathrm{pH}$ dilakukan untuk mengetahui $\mathrm{pH}$ edible film yang diformulasi sesuai dengan $\mathrm{pH}$ fisiologis mulut agar tidak menimbulkan reaksi iritasi pada saat penggunaan edible film. Pemeriksaan $\mathrm{pH}$ edible film dilakukan selama 6 minggu. Nilai rata - rata $\mathrm{pH}$ edible film yang didapatkan berkisar antara 6,19-6,84. Hasil pengukuran menunjukkan $\mathrm{pH}$ memenuhi rentang $\mathrm{pH}$ fisiologis mulut yaitu berkisar antara 5,5 - 7,9 (Barman dan Umesh, 2015).

\section{Pengukuran ketebalan}

Pengukuran ketebalan edible film dilakukan pada lima sisi yang berbeda, rata - rata kelima pengukuran merupakan ketebalan dari edible film. Hasil pengukurannya sebagai berikut : $\mathrm{F} 0=$ $0,01 \pm 0,004, F 1=0,02 \pm 0,02, F 2=0,05 \pm 0,007, F 3=0,052 \pm 0,008, P=0,01 \pm 0,01$. Perbedaan ketebalan edible film terjadi karena adanya perbedaan konsentrasi ekstrak yang dikandung pada masing - masing formula, dimana F3 paling tebal dibandingkan F1, F2 dan F0. Perbedaan ketebalan juga terjadi pada setiap sisi edible film yang dibuat, karena proses pembuatan menggunakan metoda casting. Sedangkan pembanding dari edible film yang sudah beredar di masyarakat menggunakan alat produksi yang lebih canggih menunjukan warna dan ketebalan yang sama pada setiap sisinya.

\section{Pengujian waktu mengembang edible film}

Pengujian ini dilakukan untuk menentukan berapa lama waktu yang dibutuhkan edible film mengembang, pecah dan melarut dimulut. Hasil uji waktu mengembang sebagai berikut : $\mathrm{F} 0=4,18$ detik, $\mathrm{F} 1=7,35$ detik, $\mathrm{F} 2=12,17$ detik, $\mathrm{F} 3=14,41$ detik dan $\mathrm{P}=3,21$ detik. Peningkatan konsentrasi ekstrak mempengaruhi waktu mengembang sediaan, dimana semakin tinggi konsentrasi ekstrak yang digunakan maka semakin lama juga edible film ini mengembang. Diduga mekanisme hancurnya film melalui mekanisme swelling dan wicking. Adapun mekanisme swelling yaitu setelah film kontak dengan air maka terjadi penetrasi air karena kapilerisasi (wicking) sehingga film mengembang dan mekanisme wicking yaitu adanya air yang ditarik oleh disintegran, maka air akan berpenetrasi masuk ke dalam pori - pori film akibatnya ikatan antar partikel menjadi lemah dan film mengembang (Kroctha, 1994).

\section{Pengujian aktifitas antibakteri terhadap Streptococcus mutans}

Pengujian dilakukan menggunakan media agar darah yang merupakan media spesifik untuk bakteri golongan alfa haemolitik yang dapat mereduksi zat besi di dalam hemoglobin sehingga dapat memberikan ciri yang khas.

Bakteri uji disuspensikan kedalam larutan $\mathrm{NaCl}$ fisiologis $0,9 \%$ karena larutan $\mathrm{NaCl}$ fisiologis merupakan lingkungan yang isotonik bagi bakteri uji. Lalu suspensi dihomogenkan dengan vortex dan diukur kekeruhannya mengunakan alat spektrofotometer UV-Vis dengan panjang gelombang 580nm transmitan 25\% (Jasril et al., 2012).

Pengujian ini menggunakan metode difusi agar dan meletakan edible film dengan diameter $5 \mathrm{~mm}$ di atas media agar darah. Hasil pengujian aktifitas edible film ektrak biji pinang menunjukan zona hambat berupa area bening rata-rata $\mathrm{F} 0=4,26 \mathrm{~mm} \pm 0,251 ; \mathrm{F} 1=14,96 \mathrm{~mm} \pm 0,0036 ; \mathrm{F} 2=15,49$ $\mathrm{mm} \pm 0,165$ dan $\mathrm{F} 3=17,05 \mathrm{~mm} \pm 0,264$. Adanya area bening yang merupakan diameter daya hambat 
menunjukkan bahwa ekstrak biji pinang mampu menghambat pertumbuhan bakteri Streptococcus mutans. Menurut penelitian yang dilakukan Zhou (2001) menjelaskan bahwa biji pinang merupakan salah satu jenis tanaman yang mengandung turunan polifenol yaitu katekin. Berdasarkan penelitian Masduki (1996) juga menjelaskan bahwa biji pinang mengandung senyawa alkaloid $1,45 \%$ yang memiliki daya antiseptik dan antibakteri. Hal tersebut dipertegas oleh Scalbert dalam Lapu dan Ngaro (2001) bahwa biji pinang juga mengandung tanin yang dapat menghambat pertumbuhan bakteri dengan cara mengikat enzim ekstraseluler sehingga aktivitas enzim akan terhambat dan proses metabolisme sel bakteri akan terganggu dan pertumbuhan bakteri juga terganggu.

\section{KESIMPULAN}

Berdasarkan penelitian yang telah dilakukan ekstrak biji pinang dalam bentuk edible film dapat menghambat pertumbuhan Streptococcus mutans yang termasuk katergori kuat.

\section{UCAPAN TERIMAKASIH}

Terima kasih kepada semua tim yang membantu dalam penelitian ini sehingga terciptanya suatu produk Edible film dari ekstrak biji pinang.

\section{DAFTAR PUSTAKA}

Arifin, M. F., Nurhidayati, L., Syarmalina, dan Rensy. 2010. Formulasi Edible Film Ekstrak Daun sirih (Piper betle L.) sebagai Antihalitosis. Jurnal Ilmu Kefarmasian Indonesia,Jakarta.

Barman, I., G, Umesh Chandra P. 2015. Effects of Habitual Arecanut and Tobacco Chewing on Resting Salivary Flow Rate and pH. Int. J. Oral Health Med Res;2(1):13-18.

Brotosoetarno, S., 1997. Peran Serta Mikroorganisme dalam proses Terjadinya Karies Gigi, Jurnal Kedokteran Gigi Universitas Indonesia, Volume 7, Edisi Khusus KPPIKGIX, FKG Universitas Indonesia, Jakarta.

Cortelli, J. R, Barbosa, M. D. S., and Westphal, M. A., 2008. Halitosis: A Review of Associated Factors and Theraupetic Approach, Braz Oral Res, 22(1): 44-54.

Departemen Kesehatan Republik Indonesia. 1979. Farmakope Indonesia, Edisi III. Direktorat Jenderal POM: Jakarta.

Departemen Kesehatan Republik Indonesia. 1995. Farmakope Indonesia, Edisi IV. Direktorat Jenderal POM: Jakarta.

Febriani, Y., Hidayat, S., and Seftiana, S., 2014. Aktivitas Anti Cacing Ekstrak Etanol Biji Pinang (Areca catechu L.) Terhadap Ascaridia galli. Indonesia Journal of Pharmaceutical Science and Tehnology. Vol 3 No.2.

Krochta, J.M. 1992. Control of Mass Transfer in Food with Edible Coating and film, advances in food Engineering, CRC Press, Boca Raton, F. L. 517-538.

Krochta, J.M., EA Baldwin., and MO Nisperos-Carriedo., 1994. Edible Coatingand Film to Improve Food Quality, Technomic Publishing Company, New York.NY.

Lapu, P. Dan N.R. Ngaro. 2001. Pengaruh In Vitro Ekstrak Daun Nimba (Azadirachata indica) terhadap Bakteri Patogen Udang Windu (Vibrio Alginolyticus). Journal Biosains 6(2) : 4953

Masduki, Imam.1996. Efek Antibakteri Ekstrak Biji Pinang (Areca catechu) Terhadap S. Aureus dan E. Coli In Vitro. Cermin Dunia Kedokteran 109 : 21-23.

Michalek, S. M., and Mc Ghee, J. R., 1982, Dental Microbiology, 4th Ed., 680-687, Harper \& Raw Publisher, Philadelphia.

Panjaitan, RR. 2008. Pengembangan Pemanfaatan Sabut Pinang untuk Pembuatan Asam Oksalat. Berita Litbang Industri Media Publikasi dan Komunikasi Peneliti Industri Vol.39 No.1. Juli 2008

Pratiwi, Rini. 2005. Perbedaan daya hambat terhadap Streptococcus mutans dari beberapa pasta gigi yang mengandung herbal. J Dent; $38: 64-67$.

Van de Broek., Feenstra, L., and de Baat, C., 2007. A Review of the Current Literature on Management of Halitosis, Journal of Oral Disease, 14: 30-39. 
Voigt, R. 1995. Buku Pelajaran Teknologi Farmasi Edisi V, Diterjemahkan oleh S. Noer, Universitas Gadjah Mada Press, Yogyakarta.

Widagdo, Yanuaris dan Suntya, Kristina. 2007. Volatile Sulfur Compounds Sebagai Penyebab Halitosis. Denpasar: Kumpulan jurnal FKG Universitas Mahasaraswati. Volume 5 No 3. Halaman 2.

Zhou, H. James. 2001. Composition and Method for Inhibiting Oral Bacteria. US Patent 20. $1 \mathrm{hlm}$. http//www.patentstorm.us/patent/6319523-description.html.7 Maret 2007. 